\title{
Effect of Nd: YAG Low Level Laser Therapy on human periodontal ligament cells: A preliminary in-vitro study
}

\author{
Ioannis D Prevezanos*, Ioannis K Karoussis, Andreas S Gkogkos, Kleopatra E Marcopoulou, Kyriaki \\ Kyriakidou, Anastasia Chernysheva and Ioannis A Vrotsos
}

Department of Periodontology, National and Kapodistrian University of Athens, Greece

Received: February 13, 2018; Published: February 26, 2018

*Corresponding author: Ioannis D Prevezanos, School of Dentistry, Department of Periodontology, National and Kapodistrian University of Athens, 2 Thivon str, Goudi, 11517, Athens, Greece, Tel: 306974094324; Email: piraeusperio@gmail.com

\section{Abstract}

Aim: To investigate the effect of Nd:YAG (1064-nm) laser irradiation on human periodontal ligament cells, concerning proliferation, differentiation and certain growth factors secretion: vascular endothelial growth factor (VEGF), epidermal growth factor (EGF) and basic fibroblast growth factor (bFGF).

Materials and Methods: Primary PDL cell cultures were irradiated with Nd: YAG laser (1064-nm), for 20, 40, 60 and 120 seconds (energy densities: $2.6-15.8 \mathrm{~J} / \mathrm{cm}^{2}$ ) and evaluated after 24 and 72 hours. Controls were not irradiated. The experiment was performed in duplicate. Data analyzed by Students t-test $(\mathrm{p}<0.05)$.

Results: Cell cultures irradiated for 40,60 and 120 seconds revealed higher proliferation when compared to controls, 24 and 72 hours after irradiation. Statistical significance was reached for the group of $60 \mathrm{~s}$ at $24 \mathrm{~h}$ and for groups of $40 \mathrm{~s}$ and $120 \mathrm{~s}$ at $72 \mathrm{~h}(\mathrm{p}<0.05)$. Alkaline phosphatase (ALP) levels were also found increased for most of the irradiated cell cultures compared to controls. Statistical significance was reached for the 120 s cultures at $24 \mathrm{~h}$ as well as for the $20 \mathrm{~s}$ at $72 \mathrm{~h}(\mathrm{p}<0.05)$. Growth factors' levels for irradiated cultures and controls were arbitrary during the experiment.

Conclusion: Within the limitations of this study, Nd:YAG (1064-nm) LLLT with the energy densities applied, increased PDL cells proliferation 24 and 72 hours after irradiation. Further studies need to confirm these results and to reveal any influence on ALP levels and growth factors secretion.

Key words: Differentiation, Growth Factors; LLLT; PDL cells; Proliferation

Abbreviations: PDL: Periodontal Ligament; LLLT: Low Level Leaser Therapy; NDYAG: Neodymium-Doped Yttrium Aluminium Garnet; VEGF: Vascular Endothelial Growth Factor; EGF: Epidermal Growth Factor; BFGF: Basic Fibroblast Growth Factor; ALP: Alkaline Phosphatase

\section{Introduction}

Low Level Laser Therapy (LLLT) has been used for several years, in many clinical applications in Medicine and Dentistry. These low-level doses of radiation enhance healing process and result in pain relief $[1,2]$. However, the exact biological mechanisms that explain LLLT's effect are still a matter of research. The major absorbing structures for the red visible and near infra-red laser wavelengths used in LLLT are most likely proteins [3]. Several studies have suggested that either elements in the mitochondrial cytochrome system or endogenous porphyrins in the cell are the energy-absorbing chromophores of LLLT. Irradiation with red and near infrared light can lead to the activation of mitochondrial respiratory chain components and the initiation of a signaling cascade which promotes cellular proliferation and growth factor's expression. More specifically, laser irradiation results in an increase of calcium release from the mitochondria to the cytoplasm [4]. At low laser doses an increase of $[\mathrm{Ca}++]$ in the cytoplasm triggers mitosis and enhances cell proliferation which could explain the bio-stimulatory effect of lasers on cell cultures [5,6]. Those doses can promote cellular proliferation in a wavelength- and dosagedependent manner.

The relevance of some irradiation parameters still remains an important area for further research [7]. The undifferentiated periodontal ligament cells (PDL) known as pluripotent ligament cells, have the ability to differentiate either to osteoblasts, or cementoblasts, or adipose cells, or fibroblasts $[8,9]$. Therefore, those cells have a major role in the regeneration of periodontal 
tissues, lost from periodontal diseases. New cementum, new bone and new periodontal fibers can derive from those cells [10,11]. LLLT is mostly applied with diode lasers (810-980-nm) or neodymiumdoped yttrium aluminum garnet (Nd: YAG) lasers (1064-nm) [1]. Few studies, mostly using diodes, have focused on the influence of LLLT on PDL cells proliferation and differentiation, supporting a positive effect [12-15]. Nevertheless, literature data about the possible effect of Nd: YAG laser, are not sufficient. A positive upgrowth stimulation of PDL cells regenerative potential could be very important in both non-surgical and surgical periodontal therapy. Growth factors are protein molecules regulating cell proliferation and differentiation, which can lead to increased wound repair in clinical conditions.

EGF is a mitotic growth factor increasing chemotaxis while decreasing extracellular matrix production in the PDL cells [16]. On the contrary, it limits the differentiation, by expression of its receptor, EGF-R, which inhibits the differentiation process [17]. Studies have shown that VEGF is associated with bone remodeling, in particular with the proliferation [18] and differentiation of osteoclasts [19]. Regarding bFGF, it appears to promote the proliferation of PDL cells and osteoblasts in a dose-response pattern. In contrast, it does not appear to be related to cellular differentiation [20]. The aim of the present study was to investigate the possible effect of Low Level Nd: YAG (1064-nm) Laser irradiation on human PDL cells concerning proliferation, differentiation and certain growth factors expression [vascular endothelial growth factor (VEGF), epidermal growth factor (EGF) and basic fibroblast growth factor (bFGF)], known to promote mitosis and wound healing.

\section{Material and Methods}

\section{PDL Culture Establishment}

Table 1: Mean values, standard deviation (SD), level of statistical significance $(p<0,05)$ per group and time point, concerning number of cells for irradiated and non-irradiated cells at 24 and 72 hours.

\begin{tabular}{|c|c|c|c|}
\hline & 24 hours & & $\begin{array}{c}\text { p-value* vs } \\
\text { controls }\end{array}$ \\
\hline & Sample No (N) & Mean values (SD) & \\
\hline control & 4 & $48750(3775)$ & \\
\hline $20 \mathrm{~s}$ & 4 & $41500(5000)$ & 0.0599 \\
\hline $40 \mathrm{~s}$ & 4 & $68000(32660)$ & 0.2860 \\
\hline $60 \mathrm{~s}$ & 4 & $55250(3304)$ & 0.0411 \\
\hline $120 \mathrm{~s}$ & 4 & $62750(25708)$ & 0.3226 \\
\hline & $\mathbf{7 2}$ hours & & \\
\hline control & 4 & $83500(39879)$ & \\
\hline $20 \mathrm{~s}$ & 4 & $112000(60155)$ & 0.4597 \\
\hline $40 \mathrm{~s}$ & 4 & $177500(21871)$ & 0.0061 \\
\hline $60 \mathrm{~s}$ & 4 & $148000(69224)$ & 0.1575 \\
\hline $120 \mathrm{~s}$ & 4 & $147000(21572)$ & 0.0311 \\
\hline
\end{tabular}

Biopsies of periodontal ligaments were obtained from two extracted, due to orthodontic reasons premolars (free of carries and gingival inflammation), of two healthy non-smoking donors (aged 24 and 26 years), under approved guidelines set by the Human Ethics Board of National and Kapodistrian University of Athens, School of Dentistry. The premolars were thoroughly washed with sterile saline and periodontal ligament tissues of roots' mid-thirds were removed with scalpels No15 (Table 1). Two primary cell cultures of periodontal ligament cells (PDL) were established 15 days after biopsies extraction. Cell cultures grew on standard conditions $\left(5 \% \mathrm{CO}_{2}\right.$ and $37 \mathrm{oC}, 85 \%$ humidity) in Dulbecco's Modified Eagle's Medium (DMEM; Gibco Grand Island, NY), supplemented with $10 \%$ fetal bovine serum (FBS, Grand Island, NY), $100 \mathrm{U} / \mathrm{ml}$ penicillin G sodium, $100 \mathrm{mg} / \mathrm{ml}$ streptomycin sulfate, and 250pg/ml amphotericin B (Gibco, Grand Island, NY).

PDL cells were trypsinized and seeded at 12 -well $(3.8 \mathrm{~cm} 2$ surface) multiwall plates (10000cells/ml) in DMEM 10\% fetal bovine serum (FBS). After the first passage (cells reached $80 \%-$ $85 \%$ confluence), cultures were subjected to immunomagnetic cell sorting using STRO-1 (BioLegend, San Diego, CA, USA) and antiIgM Microbeads (Miltenyi Biotec, Bergisch Gladbach, Germany) according to the manufacturers' instructions (MACS; Miltenyi Biotec, Bergisch Gladbach, Germany), in order to determine the cells' type (periodontal ligament cells). All experiments were performed at $7^{\text {th }}$ cells passage, in duplicate. Before laser irradiation, the medium of samples and controls was completely removed and replaced with serum free DMEM (Table 2).

Table 2: Mean values, standard deviation (SD), level of statistical significance $(p<0,05)$ per group and time point, concerning Alkaline phosphatase levels (IU/lt) for irradiated and nonirradiated cells at 24 and 72 hours.

\begin{tabular}{|c|c|c|c|}
\hline & 24 hours & & $\begin{array}{c}\text { p-value* vs } \\
\text { controls }\end{array}$ \\
\hline & Sample No (N) & $\begin{array}{c}\text { Mean values } \\
\text { (SD) }\end{array}$ & \\
\hline control & 4 & $7.75(2.63)$ & \\
\hline $20 \mathrm{~s}$ & 4 & $7.75(1.71)$ & 1.0000 \\
\hline $40 \mathrm{~s}$ & 4 & $9.5(3.51)$ & 0.4554 \\
\hline $60 \mathrm{~s}$ & 4 & $10.75(2.99)$ & 0.1823 \\
\hline $120 \mathrm{~s}$ & 4 & $13.25(3.30)$ & 0.0404 \\
\hline & 72 hours & & \\
\hline control & 4 & $12(3.92)$ & 0.0280 \\
\hline $20 \mathrm{~s}$ & 4 & $18(1.41)$ & 0.2413 \\
\hline $40 \mathrm{~s}$ & 4 & $15.5(3.70)$ & 0.6202 \\
\hline $60 \mathrm{~s}$ & 4 & $10.75(2.75)$ & 0.9106 \\
\hline $120 \mathrm{~s}$ & & $12.25(1.71)$ & \\
\hline
\end{tabular}

\section{Laser Irradiation}

Irradiation underwent using Nd: YAG laser device (1064-nm, DEKA ${ }^{\circledR}$ Smart file) with a fabricated hand piece (manipolo per terapia N40601). The laser beam was directed perpendicularly to the cell level from a distance of $5 \mathrm{~mm}$ (Figure 1). Cultures were irradiated on day 0 , for 20, 40, 60 or 120 seconds. Laser settings were: Power: 0.5W, Energy: 50mJ, Frequency: $10 \mathrm{~Hz}$, pulse duration $\geq 700 \mu \mathrm{sec}$. Energy densities were 2.6, 5.3, 7.9 and 15.8 
$\mathrm{J} / \mathrm{cm} 2$ for $20 \mathrm{~s}, 40 \mathrm{~s}, 60 \mathrm{~s}$ and $120 \mathrm{~s}$ respectively. The effect of laser irradiation on these primary cell cultures was evaluated after $24 \mathrm{~h}$ and $72 \mathrm{~h}$. Non irradiated cell cultures were used as controls. The experiment was performed in duplicate.

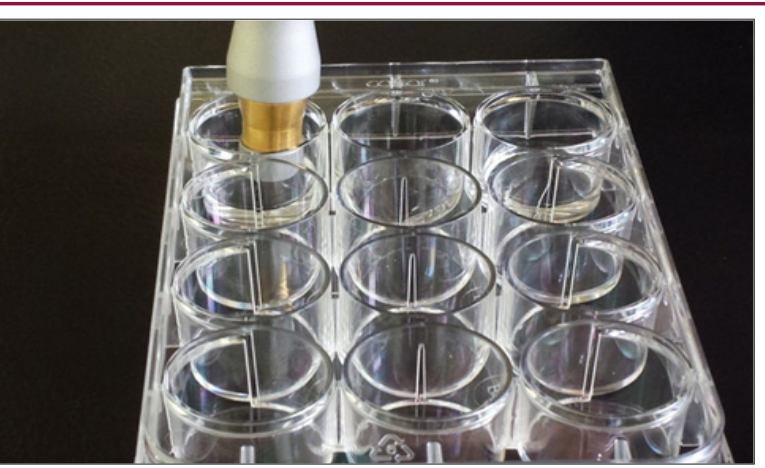

Figure 1: PDL cells' culture irradiation using Nd: YAG laser and a special hand piece (manipolo per terapia N40601) from a distance of $5 \mathrm{~mm}$ from cell layer.

\section{Proliferation Assessment}

In order to evaluate cells' proliferation, cell count was performed at the abovementioned time points for both irradiated and control samples. Cell count was performed with the use of inverted optical microscope (Zeis®) after thrypsinisation (0,05\% thrypsin/EDTA in PBS for 5 minutes) and hemacytometer assisted cell counting, by an experienced blinded (the examiner was not aware of the treatment or each culture) biologist.

\section{Differentiation Assessment}

Alkaline phosphatase levels are a reliable marker of assessing the differentiation of those pluripotent cells into premature osteoblastic cells [21]. Alkaline phosphatase activity of irradiated and control PDL cells was detected using colorimetric assays. From every sample, $2 \mathrm{ml}$ of supernatant collected and mixed with a buffer of diethylamine (1mmol/l diethylamine, $0.5 \mathrm{mmol} / \mathrm{l}$ Clorium Magnesium, pH: 9.8, 37oC) and pNPP (10 mmol/ml p-nitro-phenylophosphoric acid). These mixed collections were incubated at $37 \mathrm{oC}$ for 40 minutes. Alkaline phosphatase activity was assessed with the use of a photometer at 405-nm, by estimation of $\mathrm{p}$-nitrophenol absorption, and calculated in units (every unit corresponds in $1 \mu \mathrm{mol} / \mathrm{L}$ paranitrophenol enfranchised every minute at $37 \mathrm{oC}$ and pH9,8, Calcium kit, Sigma-Aldrich and Procedure No. 0150, Stanbio Laboratory).

\section{Growth Factors Secretion}

Irradiated and control cultures were examined for growth factors secretion (VEGF, EGF and bFGF) by molecular techniques using Luminex technology at the established time points. Luminex's XMAP® (Multi-Analyte Profiling) technology, allows simultaneous analysis of up to 500 bioassays from a small sample volume, by reading biological tests on the surface of microscopic polystyrene beads called microspheres.

\section{Data Analysis}

To investigate differences in cells number between each test group and controls Students t-test was used. For the comparison of growth factors levels (VEGF, EGF and bFGF) the change from the baseline measurements in each group was used and Students t-test was performed for the comparison between (Figure 1). All tests were two-sided and $\alpha=5 \%$ level of statistical significance.

\section{Results}

\section{Proliferation}

At the $24 \mathrm{~h}$ time point most of the irradiated groups (40s, 60s and 120 s or $5.3,7.9$ and $15.8 \mathrm{~J} / \mathrm{cm} 2$ ) showed higher cell population compared to controls, with the 60 s group reaching statistically significant higher cell population $(\mathrm{p}<0.05)$. At the $72 \mathrm{~h}$ time point, cell populations of all irradiated cultures $(20 \mathrm{~s}, 40 \mathrm{~s}, 60 \mathrm{~s}$ and $120 \mathrm{~s}$ or 2.6, 5.3, 7.9 and $15.8 \mathrm{~J} / \mathrm{cm}^{2}$ ) were higher compared to controls with the 40 s and 120 s groups reaching statistical significance $(\mathrm{p}<0.05)$. The minimum cells population was observed for the 20s cultures at $24 \mathrm{~h}$ time point, whereas the maximum was observed for the $40 \mathrm{~s}$ cell cultures at $72 \mathrm{~h}$ time point (Figure $2 \& 3$ ) and (Table 1 ).

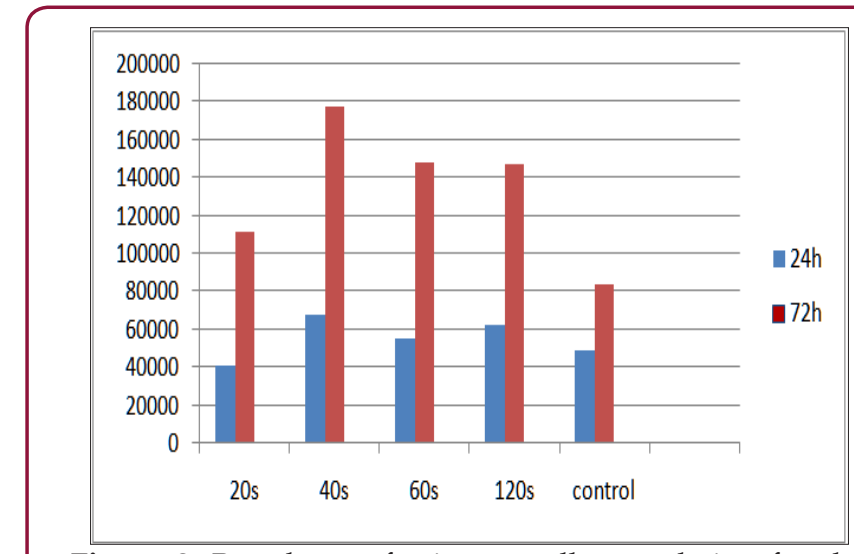

Figure 2: Bar chart referring to cells population for the irradiated and control cultures, at the established time points.
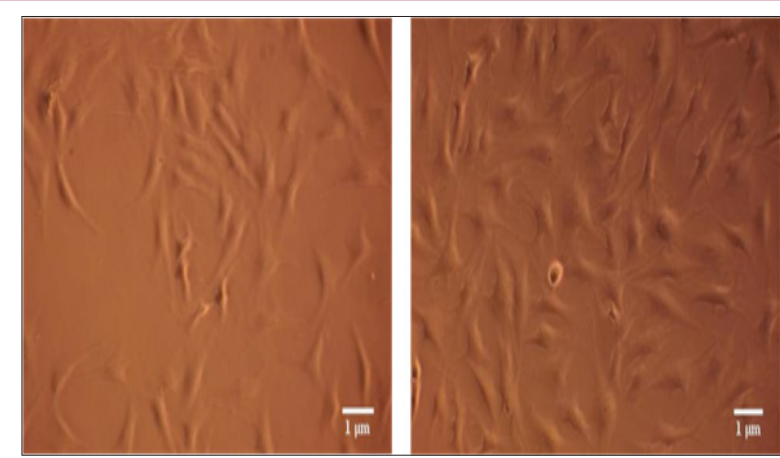

Figure 3: Photos taken from optical microscope (magnification $x 100$ ) showing the control cell culture at the left picture and the 40s group culture at the right picture, 72 hours after laser irradiation.

\section{ALP Activity}

ALP levels were also increased at most of the irradiated cell cultures compared to controls. Irradiation for 20s and 120 s led to a statistically significant increase of ALP levels compared to controls, $72 \mathrm{~h}$ and $24 \mathrm{~h}$ after irradiation respectively $(\mathrm{p}<0.05)$. The effect of laser irradiation is illustrated on (Figure 4) and (Table 2) 


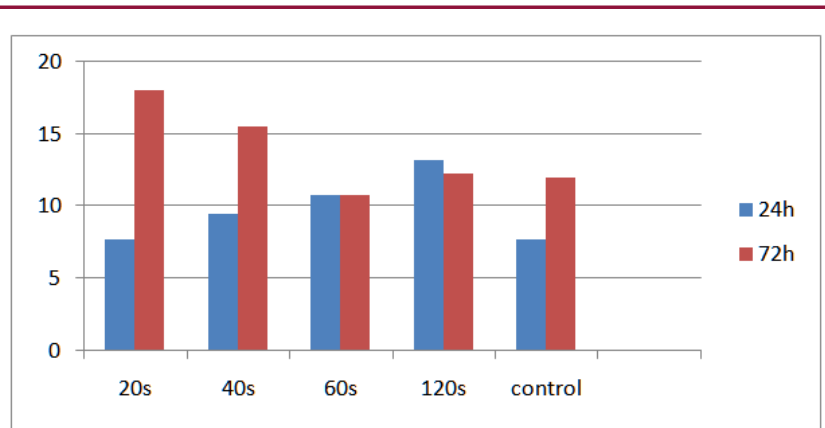

Figure 4: Bar chart referring to ALP levels (IU/lt) for the irradiated and control cultures at the established time points.

\section{Growth Factor Expression}

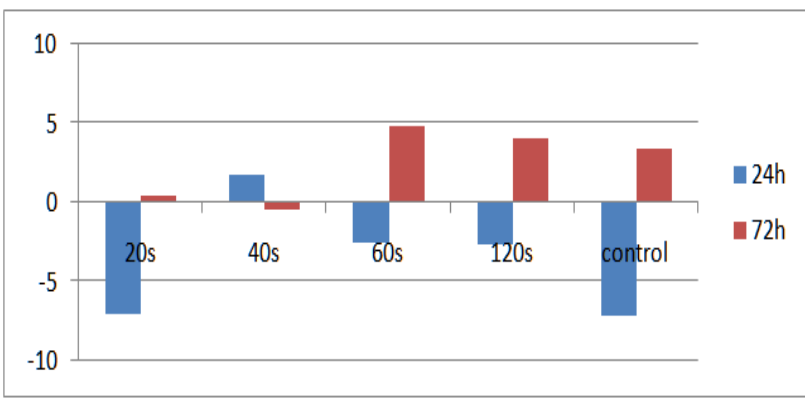

Figure 5: Bar chart showing changes from baseline levels $(70,75 \mathrm{pg} / \mathrm{ml})$ of EGF, 24 and 72 hours after irradiation.

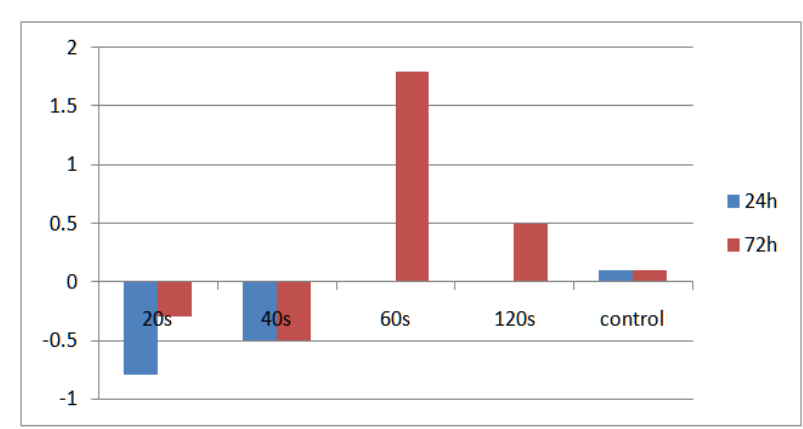

Figure 6: Bar chart showing changes from baseline levels $(9,5 \mathrm{pg} / \mathrm{ml})$ of b-FGF, 24 and 72 hours after irradiation.

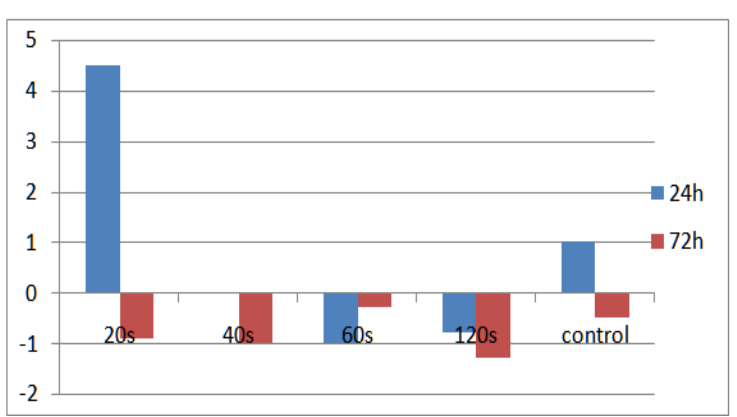

Figure 7: Bar chart showing changes from baseline levels $(14 \mathrm{pg} / \mathrm{ml})$ of VEGF, 24 and 72 hours after irradiation.

The comparison of EGF, b-FGF and VEGF levels between irradiated and control cultures didn't show any statistically significant difference at the established time points. EGF levels of cultures irradiated for 40 s increased from baseline at the 24 hour time point while the highest EGF levels were observed for the cultures irradiated for $60 \mathrm{~s}, 72 \mathrm{~h}$ after irradiation (Figure 5). Concerning b-FGF, 60s and 120s of irradiation led to the highest levels at 72 hours, which were additionally higher than controls (Figure 6). Finally, the VEGF levels for the cultures irradiated for 20s were the highest among the groups at the 24 hours time point (Figure 7).

\section{Discussion}

There is enough scientific evidence to support the positive effect of Low level laser irradiation on wound healing [2] and proliferative effect on fibroblasts and osteoblasts [22-25]. Due to the few evidence about LLLT effect on PDL cells, the present study intended to investigate the effect of the 1064-nm wavelength on the proliferation and differentiation of primary human PDL cell cultures. Our results demonstrate a positive on PDL cell proliferation for the groups of 40s, 60s and 120s, $24 \mathrm{~h}$ after irradiation, while $72 \mathrm{~h}$ after treatment, all energy densities led to an increased cell population compared to the controls. LLLT with ED of $7.9 \mathrm{~J} / \mathrm{cm} 2$ led to a statistically significantly higher proliferation $24 \mathrm{~h}$ after treatment while when ED's of 5.3 and $15.8 \mathrm{~J} / \mathrm{cm} 2$ were applied, a statistical significance was reached at the $72 \mathrm{~h}$ evaluation. These results imply that LLLT with the conditions applied were safe in terms of cells viability since no dead cells were observed under the microscope at any irradiated cell culture, nor at the controls. This finding is in contrast to the results of the only other study [14] that used Nd: YAG laser for LLLT on PDL cell cultures. Chen et al. [14] found a $100 \%$ cell viability for non-irradiated cells, while a viability of 97.7, 95.4, 89.7 and $85.1 \%$ (for $3.125,6.25,9.375$ and $12.5 \mathrm{~J} / \mathrm{cm} 2$ respectively) was reported for irradiated cell cultures.

It has to be noticed that the evaluation of cell viability was performed 5 days after laser application. Interestingly, similarly to our microscopic observation on the 3rd day after treatment, Chen et al. [15] did not find signs of dead cells in their cultures. Unfortunately, no data on cell proliferation were reported and the reason of cell death remained unclear. Moreover, our results are in accordance to the findings of Kreisler et al. [13], which used a diode GaAlAs (809-nm) laser to treat PDL cell cultures [13]. The EDs used in this study were: 1.96, 3.92 and $7.84 \mathrm{~J} / \mathrm{cm} 2$. All energy densities applied contributed to a statistically significant increase of the proliferation rate $24 \mathrm{~h}(\mathrm{p}<0,001)$ and $72 \mathrm{~h}(\mathrm{p}<0,05)$ after irradiation, compared to controls. Furthermore, Soares et al. [26], found that LLLT with a diode laser $(660 \mathrm{~nm}, 30 \mathrm{~mW}$ ED: $1.0 \mathrm{~J} /$ $\mathrm{cm}^{2}$ ) has a significantly higher positive stimulatory effect on the proliferation of PDL cells [26]. The positive influence of LLLT on PDL cells proliferation is also supported by the findings of Choi et al. 2010, who reported a higher rate of proliferation, even though not statistically significant [12]. Finally, Ren et al, in a systematic review including 8 studies, concluded that the diode low-level laser showed positive effects on promoting PDL proliferation and osteogenic differentiation [27].

The present study is the first to our knowledge that investigated the influence of LLLT using a 1064-nm wavelength on ALP activity 
of human PDL cell cultures. ALP levels were increased at most of the irradiated cell cultures compared to non-irradiated. Irradiation for 20 s and 120 s led to a statistically significant increase of ALP levels compared to controls, $72 \mathrm{~h}$ and $24 \mathrm{~h}$ after irradiation respectively $(\mathrm{p}<0.05)$. These findings are in agreement with the other study that reported on the effect of Diode lasers on the ALP activity of PDL cells. In the later investigation, Choi et al. reported that diode GaAlAs (810-nm) laser irradiation on PDL cells had a positive effect on ALP secretion [14]. In this experiment, PDL cells were irradiated with EDs of: 1.97, 3.94 and $5.91 \mathrm{~J} / \mathrm{cm} 2$. ALP levels for all irradiated cell cultures were significantly higher compared to controls at 24, 48 and 72 hour time points. Data collection about VEGF, EGF and bFGF levels for irradiated cultures and controls were arbitrary during experiment and did not provide any conclusion. Molecular techniques performed, did not reveal any influence of the applied LLLTs on the selected growth factors secretion. One possible explanation for this may be either the small sample number or the specific growth factors selected whose regulation may not be affected by the certain laser settings.

The comparison of the studies focused on this issue reveals the heterogeneity in terms of wavelength, laser settings, optical fiber used, irradiation distance, methodologies etc. Nevertheless, it seems that LLLT does not lead to cell damage and certainly has a positive effect on human PDL cells. In the present study cells' irradiation was performed using a special hand piece, compared to what has been used in other studies. This hand piece provides a wider spot size, than the optical fibers (200-400nm), distributing uniformly the energy the irradiated surface. It would be of great clinical importance if increased differentiation of pluripotent PDL cells may be provoked in a tissue level, when periodontal tissue regeneration is intended. Ozcelik et al. [28] in a clinical study examined the possible additional clinical effect of LLLT on periodontal tissue regeneration with enamel matrix derivatives. Their results showed a significant positive effect on edema and pain reduction but not in other clinical parameters. The present study did not intend to elucidate in detail the effect of LLLT on human PDL cells. The Nd: YAG (1064-nm) is one of the commonly used lasers in Dentistry and Medicine. It is well documented about its safety and efficacy in therapeutically and surgical use. Considering the lack of evidence about Low Level Nd: YAG (1064-nm) Laser Therapy in PDL cells, this study aims to be the trigger for further research in that field.

\section{Conclusion}

Within the limitations of this study (small sample size), it may be concluded that LLLT on primary human PDL cell cultures using Nd: YAG (1064-nm) of certain energy densities increase cells proliferation 24 and 72 hours after irradiation. ALP activity may be positively affected at 24 and 72 hours, leading to cell differentiation of the investigated pluripotent mixed cell population. Further studies on higher sample sizes are needed to verify the Low Level Nd: YAG (1064-nm) Laser Therapy influence on PDL cells proliferation and differentiation, and to elucidate each biological pathway.

\section{References}

1. Enwemeka CS, Parker JC, Dowdy DS, Harkness EE, Sanford LE, et al (2004) The efficacy of low-power lasers in tissue repair and pain control: a meta-analysis study. Photomed Laser Surg 22(4): 323-329.

2. Woodruff LD, Bounkeo JM, Brannon WM, Dawes KS, Barham CD, et al. (2004) The efficacy of laser therapy in wound repair: a meta-analysis of the literature. Photomed Laser Surg 22(3): 241-247.

3. Turner J, Hode L (1999) Low Level Laser Therapy. Clinical Practice and Scientific Background. Prima Books, Granges berg, Sweden.

4. Karu T (1989) Photobiology of low-power laser effects. Health Phys 56(5): 691-704.

5. Takac S, Stojanovic S (1998) Diagnostic and biostimulating lasers. Med Preg 51(5-6): 245-249.

6. Matic M, Lazetic B, Poljacki M, Duran V, Ivkov Simic M (2003) Low level laser irradiation and its effect on repair processes in the skin. Medicinski Pregled 56(3-4): 137-141.

7. Peplow PV, Chung TY, Baxter GD (2010) Laser photobiomodulation of proliferation of cells in culture: a review of human and animal studies. Photomedicine and Laser Surgery 28(1): 3-40.

8. Seo BM, Miura M, Gronthos S, Bartold PM, Batouli S, et al. (2004) Investigation of multipotent postnatal stem. Lancet 364(9429): 149155 .

9. Nagatomo K, Komaki M, Sekiya I, Sakaguchi Y, Noguchi K, et al. (2006) Stem cell properties of human periodontal ligament cells. J Periodontal Res 41(4): 303-310.

10. Flores MG, Yashiro R, Washio K, Yamato M, Okano T, et al. (2008) Periodontal ligament cell sheet promotes periodontal regeneration in athymic rats. J Clin Periodontol 35(12): 1066-1072.

11. Iwata T, Yamato M, Tsuchioka H, Takagi R, Mukobata S, et al. (2009) Periodontal regeneration with multi-layered periodontal ligamentderived cell sheets in a canine model. Biomaterials 30(14): 2716-2723.

12. Choi EJ, Yim JY, Koo KT, et al. (2010) Biological effects of a semiconductor diode laser on human periodontal ligament fibroblasts. J Periodontal Implant Sci 40(3): 105-110.

13. Kreisler M, Christoffers AB, Willershausen B, d'Hoedt B (2003) Effect of low-level GaAlAs laser irradiation on the proliferation rate of human periodontal ligament fibroblasts: an in vitro study. J Clin Periodontol 30(4): 353-358.

14. Chen YJ, Jeng JH, Jane Yao CC, Chen MH, Hou LT, et al. (2005) Long-term effect of pulsed $\mathrm{Nd}$ :YAG laser irradiation on cultured human periodontal fibroblasts. Lasers Surg Med 36(3): 225-233.

15. Wu JY, Chen CH, Yeh LY, Yeh ML, Ting CC, et al. (2013) Low-power laser irradiation promotes the proliferation and osteogenic differentiation of human periodontal ligament cells via cyclic adenosine monophosphate. Int J Oral Sci 5(2): 85-91.

16. Matsuda N, Lin WL, Kumar NM, Cho MI, Genco RJ (1992) Mitogenic, chemotactic, and synthetic responses of rat periodontal ligament fibroblastic cells to polypeptide growth factors in vitro. J Periodontol 63(6): 515-525.

17. Matsuda N, Kumar NM, Ramakrishnan PR, Lin WL, Genco RJ, et al. (1993) Evidence for up-regulation of epidermal growth-factor receptors on rat periodontal ligament fibroblastic cells associated with stabilization of phenotype in vitro. Arch Oral Biol 38(7): 559-569.

18. Kodama I, Niida S, Sanada M, Yoshiko Y, Tsuda M, et al. (2004) Estrogen regulates the production of VEGF for osteoclast formation and activity in op/op mice. J Bone Miner Res 19(2): 200-206.

19. Niida S, Kaku M, Amano H, Yoshida H, Kataoka H, et al. (1999) Vascular endothelial growth factor can substitute for macrophage colony- 
stimulating factor in the support of osteoclastic bone resorption. J Exp Med 190(2): 293-298.

20. Dereka XE, Markopoulou CE, Mamalis A, Pepelassi E, Vrotsos IA (2006) Time-and dose-dependent mitogenic effect of basic fibroblast growth factor combined with different bone graft materials: an in vitro study. Clin Oral Implants Res 17(5): 554-559.

21. Giannopoulou C, Cimasoni G (1996) Functional characteristics of gingival and periodontal ligament fibroblasts. J Dent Res 75(3): 895-902.

22. Crespi R, Covani U, Margarone JE, Andreana S (1997) Periodontal tissue regeneration in beagle dogs after laser therapy. Lasers Surg Med 21(4): 395-402.

23. Petri AD, Teixeira LN, Crippa GE, Beloti MM, de Oliveira PT, et al. (2010) Effects of low-level laser therapy on human osteoblastic cells grown on titanium. Braz Dent J 21(6): 491-498.

24. Almeida Lopes L, Rigau J, Zângaro R, Guidugli-Neto J, Jaeger M (2001) Comparison of the low level laser therapy effects on cultured human gingival fibroblasts proliferation using different irradiance and same fluence. Laser Surg Med 29(2): 179-184.

25. Arany PR, Nayak RS, Hallikerimath S, Limaye AM, Kale AD, et al. (2007) Activation of latent TGF-beta1 by low-power laser in vitro correlates with increased TGF-beta1 levels in laser-enhanced oral wound healing. Wound Repair Regen 15(6): 866-874.

26. Soares DM, Ginani F, Henriques ÁG, Barboza CA (2015) Effects of laser therapy on the proliferation of human periodontal ligament stem cells. Lasers Med Sci 30(3): 1171-1174.

27. Ren C, McGrath C, Jin L, Zhang C, Yang Y (2016) Effect of diode lowlevel lasers on fibroblasts derived from human periodontal tissue: a systematic review of in vitro studies. Lasers Med Sci 31(7): 1493-1510.

28. Ozcelik O, Cenk Haytac M, Kunin A, Seydaoglu G (2008) Improved wound healing by low-level laser irradiation after gingivectomy operations: a controlled clinical pilot study. J Clin Periodontol 35(3): 250-254.

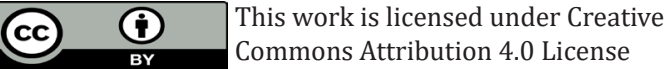

Submission Link: http://biomedres.us/submit-manuscript.php

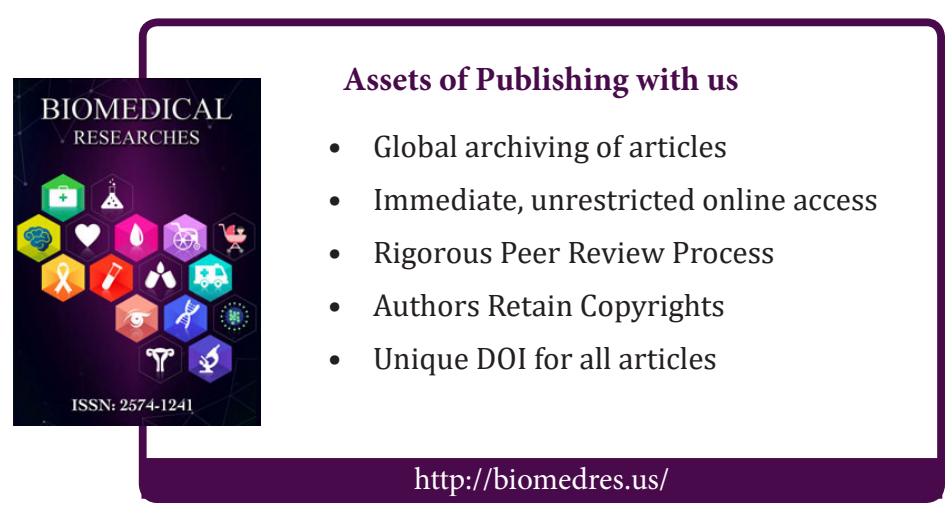

